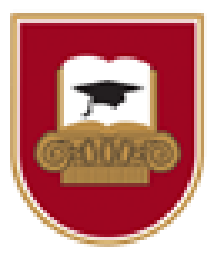

\author{
Vadyba \\ Journal of Management \\ ISSN 1648-7974
}

\title{
IMPACT OF DIVERSITY MANAGEMENT PRACTICES ON ORGANIZATIONAL CLIMATE - AN EGYPTIAN STUDY
}

\author{
Ayman Alshaabani ${ }^{1}$, Ildikó Rudnák ${ }^{2}$ \\ ${ }^{1}$ Szent István University, Hungary, ${ }^{2}$ Szent István University, Hungary
}

\begin{abstract}
This study aimed to find out which practices of diversity management can predict organizational climate, furthermore, to determine whether any demographic variable can influence the relationship between diversity management practices and organizational climate. The research questionnaire was designed and distributed to Egyptian employees working in big multinational organizations using snowball and convincing sampling methods. The results showed that not all diversity management practices (recruitment, awareness, and diversity policy) could predict trust climate or distributive justice; on the other hand, age and work experience could predict the relationship between the studied variables. Although gender had an impact on this relationship, it was not significant. These results provided a spotlight on the effects of a few diversity management practices on two of the organizational climate elements, also showing which of the demographic variables can have an impact on this relationship. This thing will be necessary for researchers who wish to focus on Egyptian literature on this topic or for managers who seek to apply diversity management practices at their companies.
\end{abstract}

KEYWORDS: diversity management practices; trust, distributive justice; age; gender; diversity policy; diversity recruitment.

\section{Introduction}

Employees are becoming diverse due to a variety of traits, which include but not limited to their cultural background, race, ethnicity, religion, sexual orientation, or any attributes that one person can have (Grobler \& Wärnich, 2002). The organizations' workforce is becoming more and more diverse as a result of; the fastchanging in the demographic characteristics of the labor market, the world shrunk and grew as a global village which leads to accelerated competency, the increased interest by the government for putting more legislations toward diversity and minorities, finally, the continues seeking from organizations for attaining and retaining talented employees regardless any unique characteristics like ethnicity or race (DeNisi \& Griffin, 2007).

This diversity created a 'double-edged sword' for organizations since it can yield both positive and negative outcomes (Milliken \& Martins, 1996). Diversity at any organization creates a competitive advantage by improving creativity and decision making (Foster \& Harris, 2005) and innovation (Agu \& FeketeFarkas, 2016). Organizations are seeking diversity for adding more positive and business-oriented approaches that enhance and improve business results in their workplace (Stuber, 2007). Thus, there are significant advantages to having a diverse workplace environment.

The friendly workplace environment encourages the employee for working efficiently, when the conditions of work are provided optimally for the employees, and they do not feel discriminated at the workplace, that help them to adjust well and enhance their retention, More loyal and attached employees to their companies mean saving the costs of training that their companies expenses (AlShubaily, 2016). It was found that a diverse workplace can improve employees' performance, turnover, decision making, and productivity (Lumby et al., 2005) creates different alternatives in decision making and creative ideas (Gajjar \& Okumus, 2018). However, a diverse workplace, on the other hand, can make an adverse workplace climate; it can lead to evil communications, low levels of social integration, turnover, conflicts, and segmentation (D. W. Pitts, 2006).

Hence, these advantages and disadvantages of diversity influenced organizations and researchers alike to draw more attention toward the importance of diversity management. Managing diversity can lead to different outcomes related to workplace climates such as trust climate (Downey, van der Werff, Thomas, \& Plaut, 2015). Organizational justice (Aldaibat et al., 2019), innovation and creativity (Bassett-Jones, 2005) and individual attachment (Gonzalez \& DeNisi, 2009) these outcomes, in turn, will affect the organization positively from a wide range of aspects, such as improved organizational productivity, job satisfaction and employees engagement (Alshaabani \& Benedek, 2018; Downey et al., 2015; Gonzalez \& DeNisi, 2009; Kim \& Park, 2017).

Therefore, managers need to understand the importance of managing diversity at the workplace in order to achieve these outcomes. It was noticed in literature that the topic of diversity management and its impacts on organizational climate had been studied widely, however, the literature which focuses on the 
middle eastern context in general and the Egyptian context especially is shallow, although Egypt has turned out to be a significant location for many international companies.

In this regard, the study is trying to answer the main question: "how can diversity management practices affect the workplace's organizational climate in the Egyptian context."

The study tries to achieve two goals:

(i) Determine which diversity management practice has impacted more on trust climate and distributive justice?

(ii) Find out whether demographical variables can predict the relationship between diversity management practices and organizational climate.

The labor market in Egypt has significant diverse characteristics between its employees; according to (CAPMAS - Central Agency for Public Mobilization and Statistics) report, the number of foreigner employees working in the Egyptian private sector reached 14.045 in 2016 (most of them are Asians) with growth $1.1 \%$ compared to 2015. The same report indicated that the majority of the Egyptian employees working in Egypt are males (nearly four doubles of females), in addition to significant differences in generations between these employees. The leading age group of employees in Egypt is between 20 to 25 (Bruni \& CAPMAS, 2017). It can be noticed that diversity exists in Egyptian companies and on different levels; therefore, diversity management practices are very important for these companies if they want to overcome the problems that they might face and to achieve the positive outcomes of diversity. So, this study tries to focus more on the Egyptian employees and the impact of diversity management practices on the organizational climate in the Egyptian companies. The thing which will fill the gap in the literature related to managing diversity practices in the Egyptian context and to managers who might be interested in understanding the importance of diversity management and its outcomes.

\section{Literature review}

\section{Diversity management practices}

There are many definitions of diversity management. However, for the purpose of this study, we will use the definition of (Cox, 1994, p. 15) who defined "managing diversity" as "planning and implementing organizational systems and practices to manage people so that the potential advantages of diversity are maximized while its potential disadvantages are minimized," from this definition it can be noticed that diversity management help the human resources management of organizations in achieving positive outcomes and reducing the negative effects of diversity at workplace.

Human Resources managers have understood the importance of having an effective diversity management practices for overcoming the difficulties related to diversity and reaping the rewards of a diverse workforce. The scholars have found that diversity management practices can help in achieving positive performance outcomes, addressing inequality in (recruitment, appraisal, advancement, and rewards) (D'Netto, Shen, Chelliah, \& Monga, 2014). It was also found, a positive relationship between diversity management practices and the employees' behaviour Such as; employees' engagement (Alshaabani \& Benedek, 2018), citizenship behaviours (Shen, D'Netto, \& Tang, 2010), employees' loyalty (Hemang \& Shailendra, 2013).

However, These effects of diversity management practices are not only related to the behaviours of the employees but also to the workplace climate such as trust climate (Downey et al., 2015) Organizational justice (Aldaibat et al., 2019 ), innovation and creativity (Bassett-Jones, 2005) organizational structure

\section{Organizational climate}

The concept of the workplace or organizational climate as a concept has gained the attention of many scholars since the 1980s (Dawson, González-Romá, Davis, \& West, 2008). It is related to the employee perceptions about supervisors' or leaders' behaviours inside a specific organization. The employees' attitudes toward their leaders' or supervisors' abilities for managing and retaining an organization's productive workforce are the key element for the continued growth of the organization (Abraham, 2019). Organizational climate is based on an idea that considers that employees' perceptions about their organization's work environment are the measure for considering an organization as good (Kanten \& Ülker, 2013). According to Bowen and Ostroff (2004, p. 205) "Organizational climate is a shared perception of what the organization is like in terms of practices, policies, procedures, routines, and rewards- what is important and what behaviours are expected and rewarded- and is based on shared perceptions among employees within formal organizational units."

Organizational workplace climate has different effects on employees' behaviours; for instance, positive workplace climate directly affects positively the training transfer which it may help to increase the organization's return on its investment (Martin, 2010), a strong relationship was found between positive organizational climate and the employees' work passion and their commitment in their organization (Permarupan, Mamun, Saufi, Noor, \& Zainol, 2013), it also leads to improve the employees' engagement (Ancarani, Mauro, \& Giammanco, 2019; Chaudhary, Rangnekar, \& Barua, 2014). Organizational climate mediates the relationship positively between leadership outcomes and organizational strategic planning (Abraham, 2019).

Burton and Obel (1998) mentioned that organizational climate has seven different dimensions; trust climate, employee morale, conflict management, rewards fairness, the levels of scapegoating, leader credibility, and resistance to change.

\section{Organizational justice}

Organizational justice refers to the degree that employees compare their situation with their peers' 
situation at a workplace, or a person's perceptions and reactions toward fairness in an organization, which in turn affects their attitudes and behaviours at work (Masterson, 2001). The exchanged theory is the basis of organizational justice, and it is seen as linked with motivation (Jang, Lee, \& Kwon, 2019). The literature of organizational justice specifies three dimensions of justice: distributive justice, procedural justice, and interactional justice (Cugueró-Escofet \& Fortin, 2014). Procedural justice concerns with the perceived fairness of the process that lead to outcomes (i.e., the perceived feeling by employees toward the fairness of decisionmaking procedures at the workplace); distributive justice, which refers to the fairness of distributing resources and outcomes of decisions; finally, interactional justice, which can be divided into informational and interpersonal justice, focuses on the social aspects (i.e., quality of treatment) (Berthelsen, Conway, \& Clausen, 2018; Girish, 2015).

As it was mentioned previously, distributive justice is dealing with rewards and the degree of fairness in its distribution; thus, we thought that this dimension of organizational justice would be the best to explain the effects of diversity management on workplace fairness' climate-related to rewards.

\section{Trust climate}

Trust is considered a crucial part of organizational climate that employees perceive, based on personal understanding for the internal workplace climate's trustworthiness (Costigan, Iiter, \& Berman, 1998), it is considered as an important tool for a positive exchange relationship (Gould-Williams \& Davies, 2005). It was defined as "the willingness of a party to be vulnerable to the actions of another party based on the expectation that the other will perform a particular action important to the trustor, irrespective of the ability to monitor or control that other party" (Mayer, Davis, \& Schoorman, 1995, p. 712); while (Rousseau, Sitkin, Burt, \& Camerer, 1998, p. 395) described it as "psychological state comprising the intention to accept vulnerability based upon positive expectations of the intentions or behaviour of another."

Trust can be distinguished into three levels: (I) trust with supervisor (II) trust with the organization; (III) trust with colleagues (Fulmer \& Gelfand, 2012). This distinction is important since there are many differences between these levels.

The impact of trust climate on the organization and employees have been widely studied in different aspects (Renzl, 2008) found that trust in management improves knowledge sharing by reducing the fear of losing one's unique value and from enhancing the person's willingness to document knowledge. Trust climate has been found as an essential effector for a variety of organizational employee's behaviors and attitudes, such as; organizational commitment, stress, job satisfaction, productivity, and turnover intentions (Dirks \& Ferrin, 2002; RM, 1999). Moreover, it was shown that trust climate associated negatively with counterproductive behaviors and positively with organizational citizenship behaviors, job performance, and employees' engagement (Alshaabani \& Benedek, 2018; Wang, Wang, \& Li, 2019). These positive impacts require proper organizational management that applies practices to build trust between the organization and its employees since the management of an organization directly affects trust at the workplace (Davis, Schoorman, Mayer, \& TAN, 2000). Therefore, the scholars in organizational theory have recognized the need for extending the current knowledge about trust climate and the circumstances under which trust can be created and improved because trust creates benefits for both organizations and employees alike.

After reviewing the literature, we could notice that the trust climate was not widely studied in the Middle Eastern context, so we preferred to focus only on it in this study because of the resource's limitation. Consequently, the focus of this study will be on only two dimensions, which are distributive justice and trust climate.

\section{Research framework and hypotheses}

\section{Diversity management practices and organizational justice}

Understanding the variations among the employees is the main focus of diversity management, also, understanding how to manage these differences in more effective and efficient ways (Deepak \& Perwez, 2019) since the actions that are done by the organization are the main influences for building the perception of justice inside the organization, it is important for any human resources management to adopt a strategy to manage the workforce diversity and bring the best out of it (Barrett, 2012). Adopting a decision making process that achieves the basic principles of organizational justice can be considered as a cause for having effective diversity management (Fujimoto, Hartel, \& Azmat, 2013).

Choi and Rainey (2013) have mentioned that organizational fairness can help in enhancing the outcomes of diversity management; when organizational fairness perceived at higher levels, the diversity's efforts for achieving higher levels of job satisfaction were more effective. Kim and Park (2017) have indicated that diversity management is influencing the perception of organizational fairness within the organization positively.

Moreover, diversity management leads to improved organizational justice at the workplace (D. Pitts, 2009). The policies of diversity management, like diversity awareness training, pay and rewards systems, performance appraisal, and career development has a positive impact on organizational justice, in the three dimensions, in the Jordanian organizations (Aldaibat et al., 2019 ). Organizations that promote effective diversity management practices in their process of recruitment and selection are more likely to attract prospective applicants, especially by minorities group and women (Avery \& Mckay, 2006; D'Netto et al., 2014).

In the same context, scholars suggested that promoting policies related to equal opportunity in the 
procedures of selection reduces the feeling of discrimination and perceived unfairness, increases the perception of justice, and generates a positive climate for diversity (Subhash, Archana, Jahanvi, \& Sandeep, 2019).

Therefore, we assume that:

H1: There is a statistically significant relationship between perceived diversity recruitment policy and distributive justice at level $(\alpha \leq 0.05)$.

$\mathrm{H} 2$ : There is a statistically significant relationship between perceived diversity awareness and distributive justice at level $(\alpha \leq 0.05)$.

H3: There is a statistically significant relationship between diversity policy on distributive justice at level $(\alpha \leq 0.05)$.

\section{Diversity management practices and trust climate}

Whitener (1997) has mentioned that positive human resources activities can find a situation where a group of employees or even individuals have the feeling of obligation toward reciprocating with positive attitudes, including trust. In particular, these activities aim to enhance communication and to empower employees to develop their skills and building supportive relationships. Human resource practices can enhance many organizational climate traits such as reward equity, organizational morale, trust climate (GouldWilliams, 2007), trust climate mediates the relationship between human resource practices and organizational outcomes (Collins \& Smith, 2006). Literature reveals a clear link between trust climate, employee well-being, and their organizational performance since the employee's performance basically depends on different aspects such as performance appraisals, payments, trust climate, job satisfaction, training and development, organizational structure, and motivations (Tzafrir, Baruch, \& Dolan, 2014).

In a diverse workplace, where differences within the workforce members can be salient, the high level of uncertainty and vulnerability that comes with the interpersonal cooperation makes trust an important element for cooperation and employee well-being (Downey et al., 2015).

Trust mediated the relationship positively between diversity management practices and employee engagement (Alshaabani \& Benedek, 2018; Downey et al., 2015). It also mediates the relationship between perceived diversity climate and team members and between perceived diversity climate and work teams (Hofhuis, van der Rijt, \& Vlug, 2016) managing diversity climate can significantly be related to trust in communications (Singh, Winkel, \& Selvarajan, 2013). Another research suggested that trust feelings and comfort at the workplace are related to the ability of and organization to manage diversity (Purdie-Vaughns, Steele, Davies, Ditlmann, \& Crosby, 2008).

Diversity management practices, such as training programs or recruitment policies, can have an important role in improving the trust climate at the workplace (Alshaabani \& Benedek, 2018). Also, it was found that having an equitable career development influence the trust between the employees toward their organization (Crawshaw \& Brodbeck, 2011). On the other hand, opening for diversity, which is an attitude of diversity awareness (Sawyerr, Strauss, \& Yan, 2005), is associated positively with trust and negatively with conflict within teams (Lauring \& Selmer, 2015). Therefore, we assume that:

H4: There is a statistically significant relationship between perceived diversity recruitment policy and trust climate at level $(\alpha \leq 0.05)$ in the Egyptian companies.

H5: There is a statistically significant impact of perceived diversity awareness and trust climate at level $(\alpha \leq 0.05)$ in the Egyptian companies.

H6: There is a statistically significant relationship between perceived diversity policy on trust climate at level $(\alpha \leq 0.05)$ in the Egyptian companies.

In the Egyptian context, the literature showed a shallow amount of studies regarding diversity management in the Egyptian context. (Elsaid, 2012) has tried to study the relationship between some diversity dimensions from surface level (such as gender, age, educational background) and the variance in employee's performance, the findings have shown that the educational background of the employee can determine his job performance whereas the age was not affecting this relationship. Mousa and Alas (2016) have studied the relationship between cultural diversity and organizational commitment, and they found that not all challenges of cultural diversity have a positive effect on the organizational commitment approaches. Badran and Khalifa (2013) have applied their study in the Egyptian hotel industry, and they have found that diversity culture, Human resources practices and the outcomes of diversity have a significant positive impact on the employees' satisfaction. Alshaabani (2019) has found that implementing diversity management practices in Egypt has a relationship with the leadership style of human resource managers.

H7: gender, age, and work experience predict the relationship between diversity management practices and distributive justice significantly.

H8: gender, age, and work experience predict the relationship between diversity management practices and trust climate significantly.

\section{Research method}

\section{Data and measurement}

A questionnaire was designed and distributed to 373 Egyptian employees working in big multinational companies in different industrial sectors in Egypt. The number of returned questionnaires was 237 suitable for statistical analysis, with a response rate of $63.6 \%$. The sample of this study was collected with snowball methods and a convenience method of collecting samples. The data was collected between the end of 2018 to April 2019.

The questionnaire was sent online as an electronic form consisting of 25 items to study the three variables through 3 sections (diversity management practices, trust climate, and distributive justice). 
The first section was about diversity management practices, and it was developed from (Downey et al., 2015) and from the researcher. It contained ten items, and the respondent could choose from a scale from 1 to 5 (1= strongly disagree, 5=strongly agree), a sample from the questions, includes " Recruitment of diverse job candidate is a priority at the company" " Diversity is a priority for the leadership." The last section was about distributive justice, which was adopted (Al-Zu'bi, 2010) and consisted of 5 items. The respondent could choose from a scale from 1 to 5 (1= strongly disagree, 5=strongly agree). Sample from the items includes: "My work schedule is fair," "Overall, the rewards I receive are quite fair."

After collecting data, the normality test for metric variables was conducted to check their normality, and the alpha Cronbach test was carried out to check the reliability of the hypotheses. The reliability test exceeded $70 \%$ for each variable, which is an acceptable percentage. Descriptive analysis (Table 1) was done for the results; correlation analysis and hierarchal multiple regression analysis were used for analyzing the results.

Table 1. Descriptive Statistics, Reliability and Pearson Correlations (N=237)

\begin{tabular}{|c|c|c|c|c|c|}
\hline Variables & $\bar{M}$ & $\begin{array}{l}\mathrm{SD} \\
\end{array}$ & 1 & 2 & 3 \\
\hline DMP & 3.29 & 0.70 & $(.79)$ & & \\
\hline Trust Climate & 3.34 & 0.71 & $.263 * *$ & (.85) & \\
\hline Distributive justice & 3.17 & 0.89 & $.113^{*}$ & $.518 * *$ & $(.82)$ \\
\hline
\end{tabular}

** Correlation is significant at the 0.01 level (2-tailed).

* Correlation is significant at the 0.05 level (2-tailed).

\section{The demographic characteristic of the sample}

The first part of the questionnaire consisted of collecting data about some demographic variables like, and it was as follows: Gender, the employees were asked to fill their gender male or female. The male's percentages were $57.1 \%$. Work experience, most of the participants were having (1 to 3 years) of experience followed with (3 to 5 years). Age groups, the majority of the employees who filled the questionnaire were between (20 to 29 years old). Table (2) shows these percentages in a more precise way.

Table 2. Demographic data of the sample study $(\mathrm{N}=237)$

\begin{tabular}{|c|c|c|c|}
\hline Demographic variables & Item & Count & Percentage \% \\
\hline \multirow{2}{*}{ Gender } & Male & 137 & 57.8 \\
\hline & Female & 100 & 42.2 \\
\hline \multirow{5}{*}{ Work experience } & less than 1 year & 33 & 13.9 \\
\hline & $1-3$ years & 65 & 27.4 \\
\hline & between 3 to 5 & 64 & 27 \\
\hline & between 5 to 10 & 56 & 23.6 \\
\hline & above 10 & 19 & 8 \\
\hline \multirow{4}{*}{ Age } & Between $20-29$ & 148 & 63 \\
\hline & Between 30-39 & 68 & 28.9 \\
\hline & Between 40- 49 & 14 & 6 \\
\hline & Older than 50 & 5 & 2.1 \\
\hline
\end{tabular}

\section{Results}

Factor analysis was performed with one as the Eigenvalue to improve the strength of the factors. The analysis extracted a three-factor solution when the rotation converged in their iteration. The three factors were perceived recruitment policy, perceived awareness training, and career development. Out of 10 items, there were four items for perceived recruitment, four items for perceived diversity awareness, and two items for perceived diversity policy (Table 3 ). 
Table 3. Rotated Component Matrix

\begin{tabular}{|c|c|c|c|c|}
\hline \multirow{2}{*}{ No. } & \multirow{2}{*}{ Item } & \multicolumn{3}{|c|}{ Component } \\
\hline & & 1 & 2 & 3 \\
\hline 1 & $\begin{array}{l}\text { Recruitment of diverse job candidates is a priority at the } \\
\text { company. }\end{array}$ & .090 & .789 & .029 \\
\hline 2 & There is organizational support for diversity-related events. & .280 & .783 & $-.016-$ \\
\hline 3 & Diversity is a priority for the leadership. & .059 & .662 & .351 \\
\hline 4 & $\begin{array}{l}\text { Diverse job candidates are actively recruited when an opening } \\
\text { exists at the organization. }\end{array}$ & .396 & .519 & .114 \\
\hline 5 & $\begin{array}{l}\text { The organization welcomes and accommodates the different } \\
\text { needs of all staff. }\end{array}$ & .697 & .191 & .161 \\
\hline 6 & $\begin{array}{l}\text { I am aware of the organization's procedures to follow it when } \\
\text { I'm harassed or believed that I have been discriminated against. }\end{array}$ & .523 & .013 & .446 \\
\hline 7 & $\begin{array}{l}\text { Top management is giving the same interest for the opinion of } \\
\text { all employees in the organizations. }\end{array}$ & .823 & .081 & .138 \\
\hline 8 & $\begin{array}{l}\text { Performance appraisal is based on equality in evaluation for all } \\
\text { employees in the organization. }\end{array}$ & .782 & .132 & .032 \\
\hline 9 & $\begin{array}{l}\text { Having a career development path for all employees at this } \\
\text { company affects my future. }\end{array}$ & .047 & .071 & .799 \\
\hline 10 & $\begin{array}{l}\text { I am interested to know more about the best methods for } \\
\text { dealing with the diverse workplace. }\end{array}$ & .232 & .140 & .711 \\
\hline
\end{tabular}

The analysis extracted a three-factor solution, each with Eigenvalues above one, which explains $59.06 \%$. This indicates that there could be more factors influencing diversity management practices when more items are generated using expert opinion and previous literature. The KMO (Table 4) was 0.79 indicating an acceptable level (Kaiser \& Rice, 1974) according to Bartlett's test for sphericity was significant $(\chi 2=$
581.391, $\mathrm{p}<0.001$ ), so, based on what was mentioned before, we could say that the three factors are accepted as a variable for diversity management practices. The Cronbach alpha for the three factors of diversity was $(0.70$ for the first factor, 0.79 for the second and 0.68 for the third one) which are acceptable percentages according to (Sekaran \& Bougie, 2016).

Table 4. KMO and Bartlett's Test

\begin{tabular}{|c|c|c|}
\hline \multicolumn{2}{|c|}{ Kaiser-Meyer-Olkin Measure of Sampling Adequacy. } & .789 \\
\hline \multirow{3}{*}{ Bartlett's Test of Sphericity } & Approx. Chi-Square & 578.088 \\
\hline & $\mathrm{df}$ & 45 \\
\hline & Sig. & .000 \\
\hline
\end{tabular}

For examining the relationship between diversity management practices, demographic variables, and trust climate, correlation and hierarchal regression analysis were employed and the same methods for this relationship with distributive justice.

Before applying a hierarchical multiple regression, the relevant assumptions related to this statistical analysis were tested, firstly, the sample size was 237 was deemed adequate given six independent variables to be included in the analysis, it is recommended 98 participants as a suitable number via the formula: $\mathrm{N}>50+6 \mathrm{~m}$ (where $\mathrm{m}$ is the number of variables) (Green, 1991). intercorrelations (see table 5) showed no variables are highly correlated to each other. The collinearity tests indicate that the data met the assumption of no multicollinearity (Coakes, 2011; Hair, Sarstedt, Kuppelwieser, \& Hopkins, 2014) (Gender; Tolerance $=.842, \mathrm{VIF}=1.18)($ Age$;$ Tolerance $=.79, \mathrm{VIF}=$ 1.26) (Work experience; Tolerance $=.69, \mathrm{VIF}=1.44$ ) (Recruitment; Tolerance $=.758, \quad \mathrm{VIF}=1.32)$ (Awareness; Tolerance $=.721, \mathrm{VIF}=1.38$ ) ( Policy; Tolerance $=.82, \mathrm{VIF}=1.21$ ) as it can be noticed, all were in the accepted limits. Moreover, an examination of Mahalanobis distance scores indicates two multivariate outliers (>22.46 for six variables), so they were eliminated. Furthermore, the data met the assumptions of independent errors (Durbin-Watson $=1.97$ ) Residual and scatter plots indicated the assumptions of normality, 
linearity, and homoscedasticity were all satisfied (Hair et al., 2014).

The three variables of diversity management practices were used as independent variables. In addition to age, gender, and work experience as controlling variables, to predict the relationship with distributive justice and trust climate as dependent variables. A two steps hierarchical multiple regression was conducted with trust and distributive justice separately as dependent variables. Age, gender, and work experience were entered as step one. Perceived recruitment, perceived diversity awareness, and diversity policy were entered in the second step.

Table 5.Intercorrelations Between Scales and Subscales $(\mathrm{N}=235)$

\begin{tabular}{|c|c|c|c|c|c|c|c|c|}
\hline & Gender & Age & $\begin{array}{c}\text { Work } \\
\text { experience }\end{array}$ & Recruitment & $\begin{array}{c}\text { Diversity } \\
\text { awareness }\end{array}$ & $\begin{array}{c}\text { Diversity } \\
\text { policy }\end{array}$ & $\begin{array}{c}\text { Trust } \\
\text { climate }\end{array}$ & $\begin{array}{c}\text { Distributive } \\
\text { justice }\end{array}$ \\
\hline Gender & 1 & & & & & & & \\
\hline Age & -.046 & 1 & & & & & & \\
\hline $\begin{array}{c}\text { Work } \\
\text { experience }\end{array}$ & $-.368 * *$ & $.425 * *$ & 1 & & & & & \\
\hline Recruitment & -.003 & $.150 *$ & .081 & 1 & & & & \\
\hline $\begin{array}{l}\text { Diversity } \\
\text { awareness }\end{array}$ & .038 & .095 & -.003 & $.459 * *$ & 1 & & & \\
\hline $\begin{array}{c}\text { Diversity } \\
\text { policy }\end{array}$ & .121 & .036 & -.066 & $.297 * *$ & $.383 * *$ & 1 & & \\
\hline $\begin{array}{c}\text { Trust } \\
\text { climate }\end{array}$ & .088 & .116 & $-.137 *$ & .090 & $.246 * *$ & $.367 * *$ & 1 & \\
\hline $\begin{array}{l}\text { Distributive } \\
\text { justice }\end{array}$ & $.180 * *$ & $.184 * *$ & -.092 & -.019 & $.139 * *$ & $.207 * *$ & $.508 * *$ & 1 \\
\hline
\end{tabular}

$\mathrm{N}=235, * * \mathrm{p}<0.01, * \mathrm{p}<0.05$

\section{Diversity management practices and distributive justice}

A hierarchical regression analysis was done to analyze the effects of perceived diversity management practices (recruitment, awareness, and policy) on distributive justice. As can be seen in (Table 6) the first step of regressions was consisting of age, gender, and work experience, in the second step, three variables were added which were (perceived recruitment, perceived awareness, and perceived diversity policy). The overall regression model predicted approximately $13.4 \%$ of the variance in distributive justice $\left(\mathrm{R}^{2}=.134, \mathrm{~F}\right.$
$(6,228)=5.88, p<0.001)$. Age and work experience only were significant, and they predicted nearly $10 \%$ of the variation in distributive justice. After controlling for age, gender, and work experience, step two predicted nearly $4.9 \%$ of the variance in distributive justice. Perceived recruitment policy is significantly predicting distributive justice negatively. On the contrary, perceived diversity policy was a significant positive predictor of distributive justice. Although it was found that perceived awareness is not significantly predicting the perceived distributive justice, with higher perceived diversity awareness, better perceived distributive justice can be gained.

Table 6. Regression analysis showing age, gender, work experience, perceived recruitment, diversity awareness, and perceived policy as predictors of distributive justice

\begin{tabular}{|c|c|c|c|c|}
\hline \multirow[t]{2}{*}{ Variables } & \multicolumn{2}{|r|}{ Cumulative } & \multicolumn{2}{|c|}{$\begin{array}{l}\text { Simultaneous } \\
\end{array}$} \\
\hline & $R^{2}$ change & $F$ change & $\beta$ & $P$ \\
\hline \multicolumn{5}{|l|}{ Step 1} \\
\hline$\overline{\text { Age }}$ & 0,085 & $\mathrm{~F}(3,231)=7.16^{*}$ & .251 & 0.001 \\
\hline Gender & & & .120 & 0.084 \\
\hline Work experience & & & -.132 & 0.05 \\
\hline \multicolumn{5}{|l|}{ Sten 2} \\
\hline Recruitment & 0,049 & $\mathrm{~F}(3.228)=4.287^{* *}$ & -.144 & 0.04 \\
\hline Awareness & & & .110 & 0.132 \\
\hline policy & & & .178 & 0.010 \\
\hline
\end{tabular}


$* \mathrm{p}<0.001, * * \mathrm{p}<0.01$

\section{Diversity management practices and trust climate}

Table (7) provides the hierarchical regression analysis results for perceived diversity management

Table 7. Regression analysis showing age, gender, work experience, perceived recruitment, diversity awareness, and perceived policy as predictors of trust climate

\begin{tabular}{|c|c|c|c|c|}
\hline \multirow[t]{2}{*}{ Variables } & \multicolumn{2}{|r|}{ Cumulative } & \multicolumn{2}{|c|}{ Simultaneous } \\
\hline & R $^{2}$ change & F change & $\bar{\beta}$ & $P$ \\
\hline \multicolumn{5}{|l|}{ Step 1} \\
\hline$\overline{\text { Age }}$ & 0,056 & $\mathrm{~F}(3,231)=4.552^{*}$ & .185 & 0.006 \\
\hline Gender & & & -.299 & 0.765 \\
\hline Work experience & & & -.194 & 0.007 \\
\hline \multicolumn{5}{|l|}{ Step 2} \\
\hline$\overline{\text { Recruitment }}$ & 0,135 & $\mathrm{~F}(3.228)=12.72 * *$ & -.083 & 0.225 \\
\hline Awareness & & & .144 & 0.042 \\
\hline policy & & & .320 & 0.001 \\
\hline
\end{tabular}

The same previously mentioned steps in distributive justice were applied. The overall regression model predicted approximately $19.1 \%$ of variance in trust climate $\left(\mathrm{R}^{2}=.191, \mathrm{~F}(6,228)=8.983, \mathrm{p}<0.001\right)$. Age, gender and work experience predicted nearly $5.6 \%$ of the variation in trust climate. After controlling for age, gender and work experience step two predicted nearly $13.5 \%$ of the variance in trust climate. Perceived diversity policy and diversity awareness were significantly predicting the trust climate positively. Even though it was found that perceived recruitment is not significantly predicting the trust climate, more perceived recruitments policies were found associated with a lower level of trust.

\section{Discussion}

This study examined the relationship between diversity management practices and trust climate and distributive justice. The results indicated that not all the studied diversity management variables could predict distributive justice; both perceived recruitment policy and perceived diversity policy predicted it however, perceived diversity awareness was not predicting distributive justice. Despite that, the study also found that diversity management practices as a model predicted the perceived distributive justice significantly especially when considering the controlling variables such as age and work experience. These findings align with the findings of (Aldaibat et al., 2019 ; Kim \& Park, 2017) the consistency may suggest that when employees perceived diversity management practices (recruitment and policy) this will be reflected in their perceptions toward distributive justice.

the same way, the results showed that diversity management practices model was significantly predicting trust climate precisely perceived diversity policy and perceived diversity awareness can predict trust climate. Like distributive justice not all diversity management practices could predict the trust climate namely, diversity awareness and diversity policy. These practices (recruitment, awareness, and policy) and trust climate in addition to the controlling variables. finding line up with (Alshaabani \& Benedek, 2018; Downey et al., 2015; Purdie-Vaughns et al., 2008). The imperial results may suggest that when employees perceived diversity management practices (awareness and policy) this will be reflected in their perceptions toward trust climate.

On the other hand, demographic variables were used as controlling variables predicting the distributive justice and trust climate, the result showed that both age and work experience can predict the distributive justice and trust climate; the more employees get older the more they are going to perceive trust climate and distributive justice, however, the more experience at work the employees have the less trust climate and distributive justice they perceive. Therefore, all hypotheses of the study were proved except the second the fourth ones, while hypotheses seven and eight were partially proved since gender didn't have any significant impact on the relationship between diversity management practices and both trust climate and distributive justice.

\section{Conclusions}

There has been a growing recognition of the importance of diversity management practices on workplace climate which in turn has different effects on the organization's performance. Therefore, this study aimed to investigate the relationship between diversity management practices. The study hypothesized that diversity management practices predict employees' perceptions toward trust climate and distributive justice. The results indicated that diversity management practices can predict trust climate and distributive justice at the organization, especially, when it is associated with age and work experience since its impact became stronger. Moreover, age and work experience were predicting the trust climate and distributive justice.

This finding of the study has both theoretical and practical implications, the scientific contribution of the paper is a filled literature gap in the relationship between 
diversity management practices and trust climate and distributive justice. Although these topics are common in the international context, however, for Middle Eastern and Egyptian context is can be considered a new study that may be interesting for both academicians and managers in Egypt who would like to initiate diversity management practices at their organizations and would like to create a positive workplace climate. In practical, the results suggest for managers to give more attention toward diversity management in their companies. Diversity training, recruitment, and policies each one has a special relationship with the trust climate and distributive justice the good manager employ these practices to achieve the desired results, with considering the age and work experience of their employees.

\section{References}

Abraham, P. A. (2019). The Mediating Role of Organizational Climate in the Relationship between Leadership Outcomes and Organizational Strategic Planning. ( $\mathrm{PhD}$ dissertation ), Hodd College, Frederick.

Agu, K. O., \& Fekete-Farkas, M. (2016). Creativity and Innovation Exploration: The Impact Of Cultural Diversity Of an Organization. Journal of Management, 28(1), 67-75.

Al-Zu'bi, H. A. (2010). A Study of Relationship between Organizational Justice and Job Satisfaction. International Journal of Business and Management, 5(12), 102-109.

Aldaibat, B. F., Alshawabkeh, Z. A. E., Feras Suliman AlShalabi, Al-Momani, R. Z., Banyhamdan, K., \& AlAbbadi, L. H. M. (2019). Implementation of Diversity Management and its Relationship with Organizational Justice: Case of Jordan. Academy of Strategic Management Journal, 18 (3).

Alshaabani, A. (2019). Impact of Personal Characteristics of Human Resources Managers on Implementation of Diversity Management Practices in Egypt. Paper presented at the Proceedings of the 7th International Conference : Inovation Management, Entrepreneurship and Sustainability (IMES 2019): 17-30, Prague

Alshaabani, A., \& Benedek, A. (2018). Trust Climate and Distributive Justice As Mediators Between Diversity Management Practices and Employees' Behaviors. Acta Carolus Robertus, 8(1), 5-16.

AlShubaily, A. (2016). Workplace Diversity Comparison between Middle Eastern and European Companies and the Exploration of Its Effects on Business Output. Imperial Journal of Interdisciplinary Research (IJIR), 2(11), 417423.

Ancarani, A., Mauro, C. D., \& Giammanco, M. D. (2019). Linking Organizational Climate to Work Engagement: A Study in the Healthcare Sector. International Journal of Public Administration, 42(7), 547-557. doi:10.1080/01900692.2018.1491595

Avery, D. R., \& Mckay, P. F. (2006). Target Practice: An Organizational Impression Management Approach to Attracting Minority and Female Job Applicants. Personnel Psychology, 59(1), 157-187. doi:10.1111/j.17446570.2006.00807.x

Badran, N., \& Khalifa, G. (2013). Diversity Management: Is it an Important Issue in Hotel Industry in Egypt? Journal of Faculty of Tourism and Hotels, Fayoum University, 7(2).

Barrett, N. H. (2012). Diversity management: The common thread binding compliance, organizational culture, and best practices. (Doctoral dissertation), CAPELLA UNIVERSITY,

Bassett-Jones, N. (2005). The Paradox of Diversity Management, Creativity and Innovation. Creativity and
Innovation Management, 14(2), 169-175. doi:10.1111/j.1467-8691.00337.x

Berthelsen, H., Conway, P. M., \& Clausen, T. (2018). Is organizational justice climate at the workplace associated with individual-level quality of care and organizational affective commitment? A multi-level, cross-sectional study on dentistry in Sweden. International Archives of Occupational and Environmental Health, 91(2), 237-245. doi:10.1007/s00420-017-1275-2

Bowen, D. E., \& Ostroff, C. (2004). Understanding Hrm-Firm Performance Linkages: The Role of The "Strength" of The Hrm System. Academy of Management Review, 29(2), 203-221.

Bruni, M., \& CAPMAS, T. M. D. A. U. o. (2017). Egypt Labour Market Report Demographic Trends, Labour Market Evolution and Scenarios For The Period 20152030. Retrieved from Egypt:

Burton, R. M., \& Obel, B. (1998). Strategic Organizational Diagnosis and Design: Developing Theory for Application (2nd ed. Vol. volume 4). London: Kluwer Academic Publishers.

Chaudhary, R., Rangnekar, S., \& Barua, M. K. (2014). Organizational Climate, Climate Strength and Work Engagement. Procedia - Social and Behavioral Sciences, 133 , doi:https://doi.org/10.1016/j.sbspro.2014.04.195

291-303.

Choi, S., \& Rainey, H. G. (2013). Organizational Fairness and Diversity Management in Public Organizations: Does Fairness Matter in Managing Diversity? Review of Public Personnel Administration, 34(4), 307-331. doi:10.1177/0734371X13486489

Coakes, S. (2011). SPSS : analysis without anguish : version 20 for Windows (1st ed.). Australia Milton, Qld. : John Wiley \& Sons.

Collins, C. J., \& Smith, K. G. (2006). Knowledge exchange and combination: The role of human resource practices in the performance of high-technology firms [Electronic version]. Academy of Management Journal, 49(4), 544560.

Costigan, R. D., Iiter, S. S., \& Berman, J. J. (1998). A MultiDimensional Study of Trust in Organizations. Journal of Managerial Issues, 10(3), 303-317.

Cox, T. (1994). Cultural Diversity in Organizations: Theory, Research and Practice: Berrett-Koehler Publishers.

Crawshaw, J., \& Brodbeck, F. (2011). Justice and trust as antecedents of careerist orientation. Personnel Review, $40(1)$, 106-125. doi:https://doi.org/10.1108/00483481111095546

Cugueró-Escofet, N., \& Fortin, M. (2014). One Justice or Two? A Model of Reconciliation of Normative Justice Theories and Empirical Research on Organizational Justice. Journal of Business Ethics, 124(3), 435-451. doi:10.1007/s10551-013-1881-1

D'Netto, B., Shen, J., Chelliah, J., \& Monga, M. (2014). Human resource diversity management practices in the Australian manufacturing sector. The International Journal of Human Resource Management, 25(9), 12431266. doi:10.1080/09585192.2013.826714

Davis, J. H., Schoorman, F. D., Mayer, R. C., \& TAN, H. H. (2000). The Trusted General Manager and Unit Performance: Empirical Evidence of a Competitive Advantage. Strategic Management Journal, 21(5), 563576.

Dawson, J. F., González-Romá, V., Davis, A., \& West, M. A. (2008). Organizational climate and climate strength in UK hospitals. European Journal of Work and Organizational Psychology, 17(1), 89-111. doi:http://dx.doi.org/10.1080/13594320601046664

Deepak, S., \& Perwez, K. (2019). Diversity Climate, Diversity Management and Diversity Leadership influences on 
Organization Justice Outcomes. Paper presented at the Proceedings of International Conference on Advancements in Computing \& Management (ICACM) 2019.

DeNisi, A. S., \& Griffin, R. W. (2007). Human Resource Management: Houghton Mifflin.

Dirks, K. T., \& Ferrin, D. L. (2002). Trust in Leadership: Meta-Analytic Findings and Implications for Research and Practice. Journal of Applied Psychology, 87(4), 611-628. doi:DOI: 10.1037//0021-9010.87.4.611

Downey, S. N., van der Werff, L., Thomas, K. M., \& Plaut, V. C. (2015). The role of diversity practices and inclusion in promoting trust and employee engagement. Journal of Applied Social Psychology, 45(1), 35-44. doi:10.1111/jasp.12273

Elsaid, A. M. (2012). The Effects of Cross Cultural Work Force Diversity on Employee Performance in Egyptian Pharmaceutical Organizations. Business and Management Research, 1(4), 162-179. doi:https://doi.org/10.5430/bmr.v1n4p162

Foster, C., \& Harris, L. (2005). Easy to say, difficult to do: diversity management in retail. Human Resource Management Journal, 15(3), 4-17. doi:10.1111/j.17488583.2005.tb00150.x

Fujimoto, Y., Hartel, C., \& Azmat, F. (2013). Towards a diversity justice management model : integrating organizational justice and diversity management. Social responsibility journal, 9(1), 148-166. doi:doi: 10.1108/17471111311307877

Fulmer, C. A., \& Gelfand, M. J. (2012). At What Level (and in Whom) We Trust: Trust Across Multiple Organizational Levels. Journal of Management, 38(4), 1167-1230. doi:10.1177/0149206312439327

Gajjar, T., \& Okumus, F. (2018). Diversity management: What are the leading hospitality and tourism companies reporting? Journal of Hospitality Marketing \& $\begin{array}{lll}\text { Management, } & \text { 27(8), }\end{array}$ doi:10.1080/19368623.2018.1465505

Girish, V. G. (2015). Diversity and Organizational Justice: The Mediating Role of Diversity Management. American International Journal of Social Science, 4(1), 64-72.

Gonzalez, J. A., \& DeNisi, A. S. (2009). Cross-level effects of demography and diversity climate on organizational attachment and firm effectiveness. Journal of Organizational Behavior, 30(1), 21-40. doi: $10.1002 /$ job. 498

Gould-Williams, J. (2007). HR practices, organizational climate and employee outcomes: evaluating social exchange relationships in local government. The International Journal of Human Resource Management, 18(9), 1627-1647. doi:10.1080/09585190701570700

Gould-Williams, J., \& Davies, F. (2005). Using social exchange theory to predict the effects of hrm practice on employee outcomes. Public Management Review, 7(1), 124. doi:10.1080/1471903042000339392

Green, S. B. (1991). How Many Subjects Does It Take To Do A Regression Analysis. Multivariate Behavioral Research, 26(3), 499-510. doi:10.1207/s15327906mbr2603_7

Grobler, P., \& Wärnich, S. (2002). Managing Human Resources in South Africa: A Guide for Internationals. Journal of Transnational Management Development, 7(4), 5-25. doi:10.1300/J130v07n04_02

Hair, J. F., Sarstedt, M., Kuppelwieser, V., \& Hopkins, L. (2014). Partial Least Squares Structural Equation Modeling (PLS-SEM): An Emerging Tool for Business Research. European Business Review, 26(2), 106-121. doi: Available at: http://works.bepress.com/joe_hair/30/

Hemang, J., \& Shailendra, S. (2013). Perceived diversity climate and employees' organizational loyalty. Equality,
Diversity and Inclusion, 32(3), 262-276. doi: https://doi.org/10.1108/EDI-12-2012-0119

Hofhuis, J., van der Rijt, P. G. A., \& Vlug, M. (2016). Diversity climate enhances work outcomes through trust and openness in workgroup communication. SpringerPlus, 5(1), 714. doi:10.1186/s40064-016-2499-4

Jang, J., Lee, D. W., \& Kwon, G. (2019). An Analysis of the Influence of Organizational Justice on Organizational Commitment. International Journal of Public Administration,

$1-9$. doi:10.1080/01900692.2019.1672185

Kaiser, H. F., \& Rice, J. (1974). Little Jiffy, Mark Iv. Educational and Psychological Measurement, 34(1), 111117. doi:10.1177/001316447403400115

Kanten, P., \& Ülker, F. E. A. (2013). The Effect of Organizational Climate on Counterproductive Behaviors: An Empirical Study on the Employees of Manufacturing Enterprises.

Kim, S., \& Park, S. (2017). Diversity Management and Fairness in Public Organizations. Public Organization Review, 17(2), 179-193. doi:10.1007/s11115-015-0334-y

Lauring, J., \& Selmer, J. (2015). Openness to diversity, trust and conflict in multicultural organizations. Journal of Management \& Organization, 18(6), 795-806. doi: $10.1017 /$ S1833367200000444

Lumby, J., Harris, A., Morrison, M., Muijs, D., Sood, K., Glover, D., . . . Middlewood, D. ( 2005). Leadership development and diversity in the learning and skills sector. London: LSDA.

Martin, H. J. (2010). Workplace climate and peer support as determinants of training transfer. Human Resource Development Quarterly, 21(1), 87-104. doi:10.1002/hrdq.20038

Masterson, S. S. (2001). A trickle-down model of organizational justice: relating employees' and customers' perceptions of and reactions to fairness. Journal of Applied Psychology, 86(4), 594-604. doi:10.1037/00219010.86.4.594

Mayer, R. C., Davis, J. H., \& Schoorman, F. D. (1995). An Integrative Model of Organizational Trust. The Academy of Management Review, 20(3), 709-734. doi: $10.2307 / 258792$

Milliken, F. J., \& Martins, L. L. (1996). Searching for Common Threads: Understanding theMultiple Effects of Diversity in Organizational Groups. Academy of Management Review, 21, 402-403.

Mousa, M., \& Alas, R. (2016). Cultural Diversity and Organizational Commitment: A Study on Teachers of Primary Public Schools in Menoufia (Egypt). International Business Research, 9(7), 154-163. doi:Http://10.5539/ibr.v9n7p154

Permarupan, P. Y., Mamun, A. A.-., Saufi, R. A., Noor, \& Zainol, R. B. (2013). Organizational Climate on Employees' Work Passion: A Review. Canadian Social Science, 9(4), 63-68. doi:10.3968/j.css.1923669720130904.2612

Pitts, D. (2009). Diversity Management, Job Satisfaction, and Performance: Evidence from U.S. Federal Agencies. Public Administration Review, 69(2), 328-338. doi:10.1111/j.1540-6210.2008.01977.x

Pitts, D. W. (2006). Modeling the Impact of Diversity Management. Review of Public Personnel Administration, 26(3), 245-268. doi:10.1177/0734371x05278491

Purdie-Vaughns, V., Steele, C., Davies, P., Ditlmann, R., \& Crosby, J. (2008). Social identity contingencies: how diversity cues signal threat or safety for African Americans in mainstream institutions. Journal of personality and social psychology, 4(94), 615-630. doi:10.1037/0022-3514.94.4.615 
Renzl, B. (2008). Trust in management and knowledge sharing: The mediating effects of fear and knowledge documentation. Omega, 36(2), 206-220. doi:https://doi.org/10.1016/j.omega.2006.06.005

RM, K. (1999). Trust and distrust: emerging questions, enduring questions. Annual Review of Psychology, 50.

Rousseau, D. M., Sitkin, S. B., Burt, R. S., \& Camerer, C. (1998). Not So Different After All: A Cross-Discipline View Of Trust. Academy of Management Review, 23(3), 393-404. doi:10.5465/amr.1998.926617

Sawyerr, O. O., Strauss, J., \& Yan, J. (2005). Individual Value Structure and Diversity Attitudes. Journal of Managerial Phsycology, 20(6), 498-521. doi:https://doi.org/10.1108/02683940510615442

Sekaran, U., \& Bougie, R. (2016). Research Methods For Business: A Skill Building Approach: Wiley.

Shen, J., D'Netto, B., \& Tang, J. (2010). Effects of human resource diversity management on organizational citizen behaviour in the Chinese context. The International Journal of Human Resource Management, 21(12), 21562172. doi:10.1080/09585192.2010.509622

Singh, B., Winkel, D. E., \& Selvarajan, T. T. (2013). Managing diversity at work: Does psychological safety hold the key to racial differences in employee performance? Journal of Occupational and Organizational Psychology, 86(2), 242-263. doi:10.1111/joop.12015

Stuber, M. T. G. (2007). Rethinking Diversity for a Global Scope: A European EMEA Perspective.

Subhash, C. K., Archana, M., Jahanvi, B., \& Sandeep, K. (2019). Diversity-focused HR practices and perceived firm performance: mediating role of procedural justice. Journal of Asia Business Studies, 13(2), 214-239.

Tzafrir, S. S., Baruch, Y., \& Dolan, S. L. (2014). The consequences of emerging HRM practices for employees' trust in their managers. Personnel Review, 33(6), 628-647. doi: https://doi.org/10.1108/00483480410561529

Wang, Q., Wang, A., \& Li, R. (2019). The Impact of Promotion Justice on Job Performance and Organizational Citizenship Behavior: The Mediating Role of Trust. Advances in Social Science, Education and Humanities Research, 345, 121-125.

Whitener, E. M. (1997). The impact of human resource activities on employee trust. Human Resource Management Review, 7(4), 389-404. doi:https://doi.org/10.1016/S1053-4822(97)90026-7

Ayman Alshaabani- PhD student, Szent István University, Doctoral School of Management and Business Administration, Field of scientific research: diversity management, organizational behaviour, and conflict management Address: H-2100 Gödöllő, Páter Károly u. 1, Hungary, Phone. +36 70213 9825. E-mail ayman.alshaabani@phd.uni-szie.hu

Ildiko Rudnak -Associate professor at Szent István University, Institute of Social Sciences, Field of scientific research: multiculturalism communication organizational culture training - coaching culture shock adaptation competences. Address: H-2100 Gödöllő, Páter Károly u. 1, Hungary, Phone. +36 30 212-7545. E-mail Rudnak.Ildiko@gtk.szie.hu. 
